\title{
ANZTLA AFFAXRS
}

I hope that by now you have registered for the forthcoming ANZTLA conference and that we will see you in Melbourne in July. You will have noticed that the cost of the conference is higher than usual, due to the high cost of accomodation in Melbourne; however you will not be disappointed with the venue and the conference program has a very now and interesting look about it. The theme 'Library administration' will obviously appeal to those who are (or hope to be) in charge of their own library, but there will also be plenty for others to look forward to. One of the new features, by the request of last year's conference, will be denominational meetings. This will be a good opportunity to explore ways and means of ensuring that your denomination's heritage is being adequately collected and preseryed. As has been the case with the American Library Association (where denominational meetings have been held for many years), everything will depend on the impetus that comes from within the group itself. I look forward to seeing new and familiar faces in Mclbourne in July.

One of the decisions which will be placed before the AGM in Melbourne will be the date of the 1995 conference in Canberra. The local organisers, led by Judith James, librarian at St Marks Library, are keen to avoid the cold of Carberra in July and to give delegates the opportunity to see Canberra's Floriade by holding the conference on the last weekend in September (29 Sept,-2 Oct.). The tradition of holding the conference in July is not a particularly long one and certainly not unchangeable, but this will depend on how convenient or inconvenient the date is likely to be for intending attenders, 
Present planning is to hold the 1996 conference in Perth. For many regular attenders, this would mean a significantly higher cost of travel, and local librarians will be looking for some assurance of getting a regular attendance before committing themselves to inviting us to this beautiful city. At the same time, we will be looking to. Perth librarians to step forward and voluteer to do the planning.

Latest information about the Style manual is that the formatting is completed and the manuscript is now in the hands of the printers. We can look forward to secing it sometime in May. The executive of the Australian and New Zcaland Association of Theological Schools has seen the publication of this work as so important to theological education within our two countries that it has contributed $\$ 2000$ towards the cost of publication, and the executive of ANZTLA has decided to match this contribution with a similar amount. Delegates at the AGM will be asked to ratify this decision. The two grants will ensure that the manual is marketed at a very affordable price.

Progress on the five-year cumulation is going more slowly, due to the huge amount of authority work and checking which has to be done. Thanks to Lawrence McIntosh and his team at the Joint Theological Library, all this is well in hand, but it will still be quite a few months before it is ready for printing.

We have recently received advice that Dr Gary Gorman, founder of the Australian religion index, is stepping down from his position as Managing Editor, due to pressurc of other commitments. It will be the task of the Board of Management to find a suitable replacement. This will not be easy, as Gary's contribution and leadership has becn outstanding.

Statistical returns are in our hands again, and I ask for your 
co-operation to make the statistician's task easier by making your contribution both prompt and accuratc. The 1993 returns mark the end of the first decade of the collection of statistics.

If you have any involvement with a local church library for know someone who has) you may be interested in recent developments within this field in Australia. It is reported that in North America, church and synagogue libraries now outnumber the combined total of all public, special and college libraries and that it is the fastest growing field of librarianship, and there is evidence of a resurgence of interest in such libraries on this side of the Pacific. Last year, the Church Library Association was formed in Adelaide, and this year (9-11 Sept.) its first conference is to be held at Nunyara in the Adelaide Hills. It is publishing a quarterly newsletter, Off the shelf, and a book about church librarics is currently being published. If you would like to know more about any of these developments, please contact Margaret Stiller $(08212$ 2599), or write to the Chureh Library Association, PO Box 2534 Adelaide SA 5001.

(Rev'd) Trevor Zweck

President

ANZTLA Newsletler 22 